\title{
Why is Death so Attractive? An Analysis of Tourists' Motives for Visiting the Hector Peterson Memorial and Museum in South Africa
}

\author{
Dr Takalani Mudzanani \\ Department of Communication Science, University of South Africa \\ Email: mudzate@unisa.ac.za
}

\author{
Doi:10.5901/mjss.2014.v5n15p570
}

\begin{abstract}
Tourism is a multifaceted sector, which is manifested in various forms, including dark tourism. One of the dark tourism sites in South Africa is the Hector Peterson Memorial and Museum, which is named after one of the pupils who died during the Soweto riots. In order to provide clarity on why tourists are attracted to a site associated with death, in this case the death of Hector Peterson, in-depth interviews were conducted with visitors to the site and museum. Consistent with the literature review, the study revealed that factors such as novelty, escapism, enhancement of kinship relations, nostalgia, education and the media played a pivotal role in motivating visitors to visit the site.
\end{abstract}

Keywords: death, dark tourism, museum, travel motivations, visitors

\section{Introduction}

Jamieson (2006:3) claims that tourism is the biggest industry in the world. According to Rogerson and Visser (2004:2), tourism gained prominence after the Second World War. As Holloway, Humphreys and Davidson (2009:45) suggest, "the long and deprived years of war led to increased desires to travel to foreign destinations". As a result, in the post-war years, tourism became an important sector of the global economy (Rogerson \& Visser, 2004:2). In its different forms, the tourism industry complements the traditional pillars of an economy, for example, mining and agriculture. Accordingly, the tourism industry plays an important role in all aspects of a nation's life, including the social, economic and cultural aspects. It is for this reason that countries across the globe began to exploit their tourism potential in a global effort to promote the advancement of humanity in all spheres of life (Smith, 1995:1).

Today, tourism is playing a major role in global economic growth and development and this role is constantly increasing in importance. In line with this, Rahmatnia, Vejdan and Ekskandarpour (2012:139) state that "tourism is very important in the world economy and it is one of the important resources of income both for developed and developing countries". In the same vein, Dieke (2003:287) asserts that "tourism is expected to foster economic growth and improve people's well-being in areas such as job creation, revenue and balanced regional development". This is clearly the reason why a growing number of nations are coming to depend on tourism economically (Ryan \& Silvanto, 2011:306). In addition, as Spiriajevas (2008:120) puts it, "the economic impact of tourism is efficient in the regions that have limited possibilities for economic development". Spiriajevas's assertion indicates that tourism development is a perfect economic development strategy for the poor regions of the world.

Tourism manifests itself in many forms. One of the many forms of tourism is dark tourism. An increasing number of tourists are falling in love with tourist attractions that are associated with death, disaster, suffering and violence. This trend is evident in Lennon and Foley's assertion (1996:198) that there has been "significant growth in tourism associated with death, disaster and depravity". The tourist's fascination with death and disaster is reinforced by Smith's statement (1996:248) that the "the memorabilia of warfare and allied products probably constitutes the large single category of tourist attractions". The sites of Christ's crucifixion and medieval executions, according to Stone and Sharpley (2008), were the first death-related tourist destinations. According to Kang, Scott, Lee and Ballantyne (2012), 3,5 million people have visited the Ground Zero site in New York. Clearly, there is increased interest in tourism offerings associated with death and disaster.

In spite of increasing interest in dark tourism offerings among tourists, Sharpley and Stone (2009:6) state that the academic literature on dark tourism "remains eclectic and theoretically fragile and consequently understanding of the phenomenon of dark tourism remains limited". According to these authors (Sharpley \& Stone, 2009), motivations for visiting dark tourism sites remain an under-researched area. Surprisingly, travel motivations are critical in that they reflect 
the needs and wants of tourists; consequently, such needs and wants are the basis for developing competitive market offerings. Without knowledge and understanding of the needs and preferences of tourists, tourism marketers are doomed to fail (Gee, Choy \& Makens, 1984).

According to Swarns (2001), sites of dark tourism in South Africa include the Apartheid Museum in Johannesburg, and the District 6 Museum in Cape Town. Other dark tourism sites include the battlefields of Isandlwana and Rorke's Drift (Seaton \& Lennon, 2004). A literature review has revealed that no study has been conducted on the travel motivations for visiting the Hector Peterson Memorial and Museum as one of the dark tourism sites in the Gauteng province of South Africa. It is against this backdrop that the study seeks to analyse what motivates visitors to visit the Hector Peterson Memorial in South Africa. The Hector Peterson Memorial and Museum were built to serve as a symbol of the trials and tribulations of the South African struggle for liberation. The attempt by the apartheid government to impose the Afrikaans language as a medium of instruction triggered what is better known as the Soweto riots and the resistance to the introduction of Afrikaans was part of the broader struggle for freedom and democracy in South Africa. In an effort to put a stop to government's intention to introduce Afrikaans as a medium of instruction, thousands of placard-waving high school learners marched through Soweto. Hector Peterson was one of the first students to be killed by the police during their confrontation with learners. This section presented the background to the study and the following section will focus on the research objectives.

\section{Research Objectives}

The growing importance of dark tourism necessitates research endeavours into dark tourism sites such as the Hector Peterson Memorial in South Africa. The objectives of this study were to analyse the factors that motivate tourists to visit dark tourism sites and to make recommendations relating to the management of the site. The next section explores a conceptualisation of dark tourism.

\section{Literature Review}

\subsection{Defining dark tourism}

To provide clarity on the conceptualisation of dark tourism, Foley and Lennon (1996:198) define it as "a phenomenon that encompasses the presentation and consumption of real and commodified death and disaster sites" (1996:198). Dark tourism has many labels. These labels include thanatourism (Seaton, 1996), morbid tourism (Blom, 2000) and black spot tourism (Rojek, 1993). In the words of Marcel (2003, in Novelli 2005:48), dark tourism may be defined as "visitations to places where tragedies or historically noteworthy death has occurred and that continue to impact of our lives". Sharpley and Stone (2009) explain dark tourism sites as "sites associated with death, suffering and the macabre". Macdonald (2009) regards dark tourism sites as "contested and awkward for the present". She maintains that these sites should be called "difficult heritage sites". According to Cole (2000), dark tourism sites thrive on the memory of death and disaster, while White and Frew (2013:28) add that ghettos and slums are also dark tourism attractions. Clearly, there is consensus among scholars that dark tourism refers to travel to sites associated with human tragedy, despite the fact that human beings generally shy away from the tragedies of life. Accordingly, the study will shed light on why tourists have a keen interest in dark tourism sites like the Hector Peterson Memorial and Museum in South Africa. The next section explains the way in which dark tourism is classified.

\subsection{Classification of dark tourism}

According to Timothy (2011:448), there are five types of dark tourism sites, namely, places of human incarceration (prisons), war and conflict-related attractions (battlefields), natural disasters (earthquakes), sites connected to death (cemeteries, murders), and morbid attractions (mental hospitals, sunken ships). This study focuses on death tourism. Seaton (1999) argues that death tourism can be divided into five categories, namely, travel to watch death, travel to sites after death has occurred, travel to graves and monuments, travel to re-enactments, and travel to synthetic sites. The focus of this study is on the reasons for visiting the Hector Peterson Memorial. Hence, the following section will review the literature on travel motivations. 


\subsection{Travel motivations}

As indicated by Gee et al (1984), travel motivations reflect the needs and preferences of tourists who are at the centre of tourism development. Pearce and Caltabiano (1983) developed a travel motivation theory, according to which tourist motivation consists of different levels, namely, relaxation needs, safety/security needs, relationship needs, self-esteem needs and development needs and self-actualisation needs. Dann (1977), on the other hand, claims that both push and pull factors motivate tourists to visit a destination. The difference between pull and push factors, according to Dann (1977:186), is that the former "refers to the tourist as subject and deal with those factors predisposing him to travel", while the latter are "factors which attract the tourist to a given resort and whose value is seen to reside in the object of travel". According to Crompton (1979), push factors are psychological while pull factors are cultural. Asworth (2002:191, in Ryan) suggests that tourists are motivated to visit dark tourism sites because of the "desire for learning experience and for satisfying curiosity about the abnormal or bizarre".

According to Crompton (1979:408), novelty, education, exploration and evaluation of self, relaxation, prestige, regression, enhancement of kinship relations and the facilitation of social interaction are travel motivations. Visitors may visit a dark tourism site because they have heritage motivations, or for historical reasons. Such tourists may include history buffs and military strategists (Smith, 1996:257). Survivor guilt may also motivate people to visit sites of death and disaster (Smith, 1996:261). Curiosity is another motivation; as Lennon and Foley (2000:58) put it, "horror and death have become established commodities on sale to tourists who have an enduring appetite for the darkest elements of human history". Change from routine is another motivation for travelling; according to Mayo and Jarvis (1981), change can be defined as new conditions of environment, psychological outcomes and lifestyles. Dark tourism motivations include pilgrimage, event validation, identity search, education and a sense of social responsibility (Hyde \& Harman, 2011).

Other motivations include escape, adventure and the role of the media. Hornby (1974) defines escape as a temporary distraction from reality and dull routine, while adventure is defined as exciting experience obtained through the medium of strange and unusual happenings (Mayo \& Jarvis 1981). For Lennon and Foley (2000:16), global communication technologies are inherent in both the events associated with dark tourism products and the representation of the events for visitors. Lennon and Foley's assertion (2000) suggests that communication technologies play an important role in motivating visitors to visit dark tourism sites. This review of the literature is followed by a discussion on the research methodology applied in this study.

\section{Research Methodology}

In order to achieve the goal set for the study, in-depth interviews were conducted with 15 visitors to the Hector Peterson Memorial and Museum to gain a deeper understanding of the research problem (Taylor \& Bogdan, 1984:80). Accordingly, in-depth interviews were used because, because as Berg (1998:61) puts it, "the in-depth interview could assist a researcher to engage in dialogue with the real person being interviewed and to relate to the interviewee as a human being and not merely a study subject". Terre Blanche and Durrheim (1999:138) recommend that notes be taken during the interviews. Therefore, in accordance with their advice (Terre Blanche \& Durrheim, 1999:141), the researcher analysed the data by looking for themes while reading and rereading the field notes and transcripts. The following section discusses the findings of this research and presents the conclusions.

\section{Findings}

As already indicated, the goal of the study was to analyse what motivates visitors to visit the Hector Peterson memorial in South Africa. According to Crompton (1979), novelty is one of the factors that motivate tourists to travel. As one of the participants in this study put it, "we are here to have fun in the historic township of Soweto". "We are experiencing something different", another participant remarked. "I have personal interest in history and heritage", another participant said. Clearly, the participants were of the view that novelty played a role in motivating them.

In line with Hornby's (1974) view, the participants agreed that they were escaping from routine. One of the participants said, "We are resting and relaxing in the township of Madiba". In the words of another participant, "we are getting away from daily routine". Consistent with Crompton (1979), the participants conceded that they had visited the site to enhance kinship relations. "I am having good time with my girlfriend", one participant remarked. "Our kids are enjoying every moment of our stay here", said another participant.

The participants also agreed that nostalgia played a role in motivating them to visit the memorial site. "I took part in the struggle and came here to reflect on our past trials and tribulations", one participant remarked. "This place is a source 
of inspiration for us to move forward in our national effort to build a better life for all", said another participant. "I am here to pay respects to those who perished during the Soweto Riots and the struggle for liberation as a whole", another participant said.

Furthermore, in line with Hyde and Herman's view (2011), education played a role in motivating the participants to visit the Memorial site and Museum. One of the participants remarked: "As a history student, I am here to learn about the Soweto riots within the broader South African struggle for freedom and democracy. As a foreign visitor I have a keen interest in South African history because there are many lessons that we can draw from it."

Some of the participants stated that they had been motivated by the media to visit the memorial site and museum. "I read about the place on the internet", one of the participants said. On the whole, it can be said that the participants' statements were consistent with scholars' views on why death is so attractive. Contextually speaking, death was attractive because of factors such as novelty, escapism, enhancement of kingship relations, nostalgia, education and the media.

\section{Conclusion and Recommendations}

This study sought to analyse factors that motivate visitors to visit the Hector Peterson Memorial and Museum. In order to achieve the goal of the study, travel motivations were analysed by means of a literature review. In addition, in-depth interviews were conducted with 15 visitors. The literature review revealed that a number of factors motivate tourists to visit dark tourism sites, including novelty, escape, enhancement of kinship relations, nostalgia, education, relaxation, education and the media. Thus, consistent with the findings of the literature review, it can be concluded that the visitors to the Hector Peterson Memorial and Museum who were interviewed were motivated by these factors.

In the light of the findings of the study, it can be recommended that the management of the Hector Peterson Memorial and Museum create a physical environment that allows for relaxation. In addition, the site should develop educational programmes that present the site as an integral part of the struggle for freedom and democracy in South Africa. Moreover, in order to heighten awareness about its market offering, the museum should embark on an integrated marketing communication campaign.

\section{References}

Berg, B.L. 1998. Qualitative research methods for social sciences. Boston: Pearson Education.

Blom, T. 2000. Morbid tourism: a postmodern market niche with an example from Althorp. Norsk Geografisk Tidsskrif 54(1):29-36.

Cole, T. 2000. Selling the Holocaust: from Auschwitz to Schindler, How history is bought, packaged and sold. New York: Routledge. Crompton, JL. 1979. Motivations for pleasure vacation. Annals of Tourism Research (6):408-424.

Dann, G. 1981. Tourist motivation: an appraisal. Annals of Tourism Research (8):187-219.

Dann, G. 1996. The language of tourism: a sociolinguistic perspective. Wallingford, Oxon: CAB International.

Dann, G.1997. Anomie, ego-enhancement and tourism. Annals of Tourism Research (4):184-194.

Dieke, PUC. 2003. Tourism in Africa's economic development: policy implications. Management Decision, 41(3):287-297.

Foley, M \& Lennon, JJ. 1996. JFK and dark tourism: a fascination with assassination. International Journal of Heritage Studies (2):198211.

Gee, CY, Choy, JL \& Makens, JC. 1984. The travel Industry. Westport, CT: AVL.

Holloway, JC, Humphreys, C \& Davidson, R. 2009. The business of tourism. Essex: Pearson Education.

Hornby, AS. 1974. Oxford advanced learner's dictionary of current English. London: Oxford University Express.

Hyde, K.F. and Harman, S. (2011), "Motives for a secular pilgrimage to the Gallipoli battlefields",Tourism Management, Vol. 32, pp. 1343-1351.

Jamieson, W. 2006. Community destination management in developing economies. New York: Haworth Hospitality.

Kang, EJ, Scott, N, Lee, TJ \& Ballantyne, R. 2012. Benefits of visiting a dark tourism site: the case of Feju April $3^{\text {rd }}$ Pearce Park, Korea. Tourism Management (33):257-265.

Lennon, JJ \& Foley, M. 1999. Interpretation of the unimaginable: the US Holocaust Museum, Washington. Journal of Travel Research (38):46-50.

Lennon, J \& Foley, M. 2000. Dark tourism: the attraction of death and disaster. New York: TJ International.

Mayo, E \& Jarvis, LP. 1981. The psychology of leisure travel. Boston, MA: CBI.

Mcdonald, S. 2009. Difficult heritage: Negotiating the Nazi past in Nuremburg and beyond. London: Routledge.

Novelli, M. 2005. Niche tourism: contemporary issues, trends and case. Oxford: Butterworth-Heinemann.

Pearce, PL \& Caltabiano, ML. 1983. Inferring rravel motivation from travellers' experiences. Journal of Travel Research 22(2):16-20.

Rahmatnia, S, Vejdan, R \& Eskandarpour, B. 2012. Cultural tourism and its role in society's economic development. American Journal of Scientific Research, Vol. 58:138-147.

Rogerson, CM \& Visser, G. (eds). 2004. Tourism and development issues in contemporary South Africa. Pretoria: Africa Institute of 
South Africa.

Rojek, C.1993 .Ways of Seeing-Modern Transformations in Leisure and Travel. London:Macmillan.

Ryan, C, Page, SJ \& Aicken, M. 2005. Taking tourism to the limits: issues, concepts and managerial perspectives. Oxford: Elsevier.

Ryan, J \& Silvanto, S. 2011. A brand for all nations: the development of the world heritage brand in emerging markets. Marketing Intelligence \& Planning, 29(3):306-318.

Seaton, A. 1996. Guided by the dark: from thanatopsis to thanatourism. International Journal of Heritage Studies (2):234-244.

Seaton, AV. 1999. War and thanatourism: Waterloo 1815-1914. Annals of Tourism Research (26):130-159.

Seaton, AV \& Lennon, JJ. 2004. Moral panics, ulterior motives and alterior desires: thanatourism in the early $21^{\text {st }}$ century. In Singh, TV (ed.), New horizons in tourism. Cambridge: CABI Publishing.

Sharpley, R \& Stone, P (eds). 2009. The darker side of travel: the theory and practice of dark tourism. Bristol: Channel View.

Smith, S.L.J. 1995. Tourism analysis. Essex: Longman

Smith, VL. 1996. War and its tourist attractions. In A. Pizan \& Y. Manfeld (eds), Tourism, crime and international security issues. Brisbane: John Wiley and Sons.

Spiriajevas, E. 2008. The impact of tourism factor for development of the South-East Baltic coastal-border regions. Geo Journal of Tourism and Geosites, 2(2):118-128.

Stone, P \& Sharpley, R. 2008. Consuming dark tourism: a thanatological perspective. Annals of Tourism Research (35):574-595.

Swarns, R.L.2001. Oppression in Black and White: South Africa Museum Recreates Apartheid.New York Times (10 December).

Terreblanche, M. \& Durrheim, K. (eds). 1999. Research in practice: applied methods for the social sciences. Cape Town: UCT Press.

Taylor, S.J. \& Bogdan, R. 1984. Introduction to qualitative research methods: the search for meanings. New York: John Wiley

Timothy, DJ. 2011. Cultural heritage and tourism: an introduction. Ontario. Channel View.

White, L \& Frew, E. 2013. Dark tourism and place identity: managing and interpreting dark places. New York: Routledge. 